activity (Regoeczi, 1970) may also occur. Additionally it seems that fibrin deposition on arteriolar walls as part of an immunological reaction can give rise to a chronic endarteritis, akin to that seen in chronic renal transplant rejection (Porter, 1967). The accelerated fibrinogen turnover in case 1 might indeed be seen as the cause of that patient's endarteritis. The occurrence of endarteritis in association with endocarditis has recently been stressed by Morel-Maroger et al. (1972). This type of lesion was recognized by Powell (1961) to occur as a result of staphylococcal septicaemia, in which condition a variety of renal lesions, from cortical necrosis to glomerulonephritis, are found. The production by staphylococci of the procoagulant coagulase is the explanation for the intravascular coagulation of staphylococcal septicaemia (Smith and Johnstone, 1958). Additionally at a later stage antibody production to the relevant antigen will result in immune complex formation in the circulation. Such circulating complexes will initiate damage to platelets (Wardle, 1972 b) and may well be responsible for a chronic low grade state of intravascular coagulation. It will occur particularly in the kidneys wherein complexes are concentrated by ultrafiltration. The process might well be perpetuated if antigen is continually accessible on the heart valves or if the patient starts to form antibodies to his own altered gammaglobulin, which is a plausible explanation for the development of rheumatoid factors. It would therefore be reasonable to associate a low serum complement, in the context of endocarditis, not only with the occurrence of immune complexes but also with intravascular coagulation. All three mechanisms could be contributory to the rapidly progressive proliferative glomerulonephritis, with crescent formation, that is often observed.

Case 2 shows that anticoagulation in this particular form of nephritis is best avoided, and case 3 shows that it may in any event be ineffective. Our own group (Wardle and Uldall, 1972), in common with others, have reported some benefit from heparinization in other forms of progressive glomerulonephritis, but that paper also notes the failure of heparin to affect the serum complement level. Case 3 again attests to this fact. Indeed the best hope for improvement in these cases lies still in classical therapy with early and large doses of antibiotics.

We are grateful to Professor D. N. S. Kerr for his support.

\section{References}

Bell, E. T. (1932). American fournal of Pathology, 8, 639.

Brodsky, I., Myer, A. N., Benham Kahn, S., and Ross, E. M. (1968). American fournal of Clinical Pathology, 50, 211.

Cordeiro, A., Costa, H., and Laginha, F. (1965). American fournal of Cardio$\log y, 16,477$.

Corrigan, J.' J., W Walker, L. R., and May, N. (1968). New England fournal of Medicine, 279, 850 .

Dixon, F. J. (1968). American fournal of Medicine, 44, 493.

Gans, H., and Krivit, W. (1961). Annals of Surgery, 153, 453.

Gutman, R. A., Striker, G. E., Gilliland, B. C., and Cutler, R. E. (1972). Medicine, 51 ,

Hjort, P. F., and Rapaport, S. I. (1965). Annual Review of Medicine, 16, 135. Kaufman, D. B., and McIntosh, R. (1971). American fournal of Medicine, 50,

McCluskey, R. T., Vassalli, P., Gloria, G., and Baldwin, D. S. (1966). New England Fournal of Medicine, 274, 696.

MacFarlane, A. S. (1963). Fournal of Clinical Investigation, 42, 346.

Messner, R. P., Laxdal, T., Quic, P. G., and Williams, R. C. (1968). Annals of Internal Medicine, 68, 746 . Morel-Maroger, L., Sraer, J. D., Herreman, G., and Godeau, P. (1972).
Archives of Pathology, 94, 205.

Porter, K. A. (1967). Fournal of Clinical Pathology, Suppl., No. 20, p. 518.

Powell, D. E. B. (1961). Fournal of Pathology and Bacteriology, 82, 141 .

Regoeczi, E. (1970). In Plasma Protein Metabolism, ed. M. A. Rothschild and T. Waldmann, chap. 30. New York, Academic Press.

Rubenberg, M. L., Baker, L. R. I., McBride, J. A., Sevitt, L. M., and Brain, M. C. (1967). British Medical fournal, 4, 271.

Smith, D. E., and Johnstone, J. M. (1958). British fournal of Experimental Pathology, 39, 165 .

Spain, D. M., and King, D. W. (1952). Annals of Internal Medicine, 36, 1086. Stehbens, W. E., Sonnenwirth, A. C., and Kotrba, C. (1969). Experimental and Molecular Pathology, 10, 295 .

Vassalli, P., and McCluskey, R. T. (1971). In Advances in Nephrology, ed. J. Hamburger, J. Crosnier, and M. H. Maxwell, vol. 1, chapt. 4. Year Book Medical Publishers, Chicago.

Wardle, E. N. (1972 a). Scandinavian fournal of Infectious Diseases, 4, 155.

Wardle, E. N. (1972 b). Fournal of the Royal College of Physicians, 7, 5.

Wardle, E. N. (1973). Quarterly fournal of Medicine, 42, 205.

Wardle, E. N., and Uldall, P. R. (1972). British Medical fournal, 4, 135.

Williams, R. C., and Kunkel, H. G. (1962). Fournal of Clinical Investigation, $41,666$.

Yoshikawa, T., Tanaka, K. R., and Guze, L. B. (1971). Medicine, 50, 237.

\title{
Acute Intermittent Porphyria: Response of Tachycardia and Hypertension to Propranolol
}

\author{
A. D. BEATTIE, M. R. MOORE, A. GOLDBERG, R. L. WARD
}

British Medical fournal, 1973, 3, 257-260

\section{Summary}

In four young adult patients with acute attacks of acute intermittent porphyria tachycardia and hypertension were prominent features of the illness. Urinary catecholamine excretion was increased in both patients in whom it was measured. The effect of the beta-adrenergic blocking drug propranolol was assessed in each case. The dose varied from 40 to $240 \mathrm{mg}$ daily. A response in the form of a reduction in heart rate and blood pressure was noted

\footnotetext{
University Department of Materia Medica and M.R.C. Group in Iron and Porphyrin Metabolism, Stobhill General Hospital, Glasgow G21 3UW

A. D. BEATTIE, M.D., Honorary Registrar

M. R. MOORE, B.SC., PH.D., Research Biochemist

A. GOLDBERG, M.D., F.R.C.P., F.R.S.ED., Regius Professor of Materia Medica

Royal Infirmary, Blackburn, Lancashire

R. L. WARD, M.D., F.R.C.P., Consultant Physician
}

in each case, and in one case a marked alleviation of abdominal pain followed administration of the drug.

Propranolol, when given in high dosage to rats, did not induce an increase in hepatic delta-aminolaevulic acid synthetase, an enzyme which is raised in human and drug-induced animal porphyria. The use of propranolol is therefore unlikely to aggravate or precipitate an attack of acute intermittent porphyria.

\section{Introduction}

Acute intermittent porphyria is an inherited metabolic error in which delta-aminolaevulic acid (ALA) and porphobilinogen (PBG) are formed excessively in the liver. Clinically it is characterized by gastrointestinal symptoms and involvement of the nervous system. Tachycardia is present in most patients during an attack and is a good index of the activity of the disease (Waldenström, 1937; Goldberg, 1959). Hypertension in acute porphyria was first described by Melkersson (1925) and has subsequently been reported in about $50 \%$ of patients during an attack (Goldberg, 1959). Papilloedema, hypertensive encephalopathy, and left ventricular failure have all been described in 
acute intermittent porphyria with cardiovascular involvement, and for this reason it is desirable to control the tachycardia and hypertension. In this paper the effects are described of the betaadrenergic blocking agent propranolol (Inderal) in four patients with cardiovascular features of acute intermittent porphyria.

Many attacks of acute intermittent porphyria are known to be precipitated by drugs, particularly of the barbiturate group. These drugs, which provoke the disease in man, have been shown in experimental animals to induce the enzyme hepatic ALA synthetase, the rate-limiting enzyme of haem biosynthesis (Granick, 1966; Moore et al., 1970). For these reasons propranolol was given to rats to determine its effect on hepatic ALA synthetase.

\section{Materials and Methods}

Clinical Study.-The patients were admitted to hospital as emergency cases. The diagnosis of acute intermittent porphyria was established in each case on the basis of quantitative estimation of urinary and faecal porphyrins and precursors. Urinary ALA and porphobilinogen were measured by the method of Mauzerall and Granick (1956). Urinary and faecal porphyrins were measured by the methods of Rimington (1961). Pulse rate was recorded six-hourly and blood pressure measured by the mercury sphygmomanometer twice daily except where the patient's condition warranted more frequent measurement. Estimations of serum urea, electrolytes, and proteins were done using standard techniques. Urinary catecholamines were done by the method of Pisano (1960). Cardiac rhythm was recorded on an electrocardiogram and an estimate of cardiac size was made by anteroposterior chest radiography. Propranolol was given to each patient in an oral dose related to the severity of the clinical state and varying from 30 to $\mathbf{4 0 0} \mathrm{mg}$ daily.

Animal Studies.-In this work Sprague Dawley rats weighing about $200 \mathrm{~g}$ were used. They were treated for four days with one daily injection of propranolol in a dose of $1 \mathrm{mg} / \mathrm{kg}$ intraperitoneally and killed on the fifth day by cervical dislocation. The liver was immediately excised and aliquots were taken for hepatic ALA synthetase and ALA dehydrase measurement. ALA synthetase was assayed by a micromodification of the method of Marver et al. (1966) as described by Dowdle et al. (1967) on a 1 in 4 liver homogenate. ALA dehydrase was assayed by the method of Moore et al. (1971).

\section{Results}

CASE 1

A 20-year-old joiner was admitted to hospital on 23 February 1967 because of a 14-month history of intermittent left loin pain. For six months he had suffered weakness of the arms with bilateral wrist-drop. Three weeks previously he had undergone cystoscopic examination of the bladder under general anaesthesia with thiopentone sodium. On admission he had a pulse rate of $98 / \mathrm{min}$ and a blood pressure of $160 / 110 \mathrm{~mm} \mathrm{Hg}$. He had bilateral wrist-drop and weakness of the arms, with some wasting of the forearm and interosseus muscles of both sides. The deep tendon reflexes were absent in the arms but knee and ankle jerks were present. No sensory impairment could be detected.
A diagnosis of acute intermittent porphyria was established on the basis of a urinary porphobilinogen excretion of up to $220 \mathrm{mg}$ daily. Other biochemical results are shown in table I.

The tachycardia and hypertension persisted at the levels noted on admission. He was treated with chlorpromazine. After one week he was given propranolol in a dose of $10 \mathrm{mg}$ six-hourly. An immediate and sustained improvement in pulse and blood pressure occurred after administration of this drug. He remained in hospital for five weeks and his general condition rapidly improved, with a steady return of the power to his limbs. On discharge the pulse rate was $58 / \mathrm{min}$ and the blood pressure $110 / 70 \mathrm{~mm} \mathrm{Hg}$. Propranolol therapy was continued for a further two months. He thereafter remained symptom-free and normotensive.

Family History.-A paternal uncle died in 1958 and search of the hospital records showed that he was a known sufferer from acute intermittent porphyria. Quantitative porphyrin studies on 20 relatives showed that the patient's father was a latent porphyric.

CASE 2

A 24-year-old male machine operator was admitted to a surgical unit in December 1970 on account of bilateral loin pain with constipation, vomiting, sweating, and palpitations. The pulse rate was $125 / \mathrm{min}$ and the blood pressure $170 / 110 \mathrm{~mm} \mathrm{Hg}$. There were no other abnormal physical findings. The electrocardiogram showed a sinus tachycardia. The patient was sedated with phenobarbitone $30 \mathrm{mg}$ three times daily but the abdominal pain continued and he was noted to be passing dark urine. A diagnosis of acute intermittent porphyria was established on the basis of a urinary porphobilinogen excretion of $61 \mathrm{mg}$ in 24 hours. Other investigative findings are summarized in table I.

Phenobarbitone therapy was stopped and he was given chlorpromazine $100 \mathrm{mg}$ three times daily. Oral propranolol $40 \mathrm{mg}$ eighthourly was added two days later. A response was noted in the pulse and blood pressure, and this became more marked when the dose of propranolol was increased to $80 \mathrm{mg}$ three times a day. He improved symptomatically over a period of two weeks, after which he was discharged with a pulse rate of $90 / \mathrm{min}$ and a blood pressure of $130 / 80$ $\mathrm{mm}$ Hg. Propranolol therapy was continued for two months after discharge. When reviewed at the outpatient clinic two months after discharge the pulse rate was $60 / \mathrm{min}$, blood pressure $100 / 60 \mathrm{~mm} \mathrm{Hg}$ and he was asymptomatic.

Family History.-Two maternal uncles were found to have died about 30 years previously at the ages of 36 and 37 years. One of these men was known to have suffered from severe abdominal colic. Testing of the patient's relatives showed that his mother's half-brother and half-sister were latent porphyrics.

\section{CASE 3}

In 1948 a 17-year-old welder was found to have acute intermittent porphyria when he developed a severe neuropathy associated with barbiturate ingestion. During the next 17 years he experienced recurrent attacks of central abdominal pain but did not require hospital admission. Between 1966 and 1970 he was admitted on 18 occasions because of abdominal pain, tachycardia, and hypertension.

On 21 January 1971 he was admitted with severe abdominal pain, vomiting, and constipation. Very high levels of porphyrin precursors were excreted in the urine, as shown in table I. The blood pressure was $240 / 150 \mathrm{~mm} \mathrm{Hg}$ and the pulse rate $140 / \mathrm{min}$. Oral bethanidine was prescribed in a dosage up to $60 \mathrm{mg}$ six-hourly but after 10 days the blood pressure was $180 / 130 \mathrm{~mm} \mathrm{Hg}$. Propranolol was started in an oral dose of $10 \mathrm{mg}$ six-hourly and the response is shown in fig. 1 .

TABLE I-Biochemical Findings in the Four Patients

\begin{tabular}{|c|c|c|c|c|c|c|c|c|c|c|}
\hline $\begin{array}{c}\text { Case } \\
\text { No. }\end{array}$ & Sex & $\begin{array}{c}\text { Age at Time } \\
\text { of Study } \\
\text { (Years) }\end{array}$ & $\begin{array}{l}\text { Urinary ALA } \\
\mathrm{mg} / 24 \mathrm{hr}\end{array}$ & $\begin{array}{l}\text { Urinary PBG } \\
\mathrm{mg} / 24 \mathrm{hr}\end{array}$ & $\begin{array}{l}\text { Urinary } \\
\text { Uroporphyrin } \\
\mu \mathrm{g} / 24 \mathrm{hr}\end{array}$ & $\begin{array}{c}\text { Urinary } \\
\text { Coproporphyrin } \\
\mu \mathrm{g} / 24 \mathrm{hr}\end{array}$ & $\begin{array}{c}\text { Faecal } \\
\text { Protoporphyrin } \\
\mu \mathrm{g} / \mathrm{g} \text { dry wt }\end{array}$ & $\begin{array}{c}\text { Faecal } \\
\text { Coproporphyrin } \\
\mu \mathrm{g} / \mathrm{g} \text { dry wt }\end{array}$ & $\underset{\mathrm{mg} / 100 \mathrm{ml}}{\text { Serum Urea }}$ & $\begin{array}{l}\text { Urinaty } \\
\text { Metadrenaline } \\
\text { + Normeta- } \\
\text { drenaline } \\
\text { mg/24 hr }\end{array}$ \\
\hline $\begin{array}{l}1 \\
2 \\
3 \\
4\end{array}$ & $\begin{array}{l}\text { M. } \\
\text { M. } \\
\text { F. }\end{array}$ & $\begin{array}{l}20 \\
24 \\
40 \\
23\end{array}$ & $\begin{array}{l}95 \cdot 2 \\
18 \cdot 1 \\
31 \cdot 2 \\
27 \cdot 6\end{array}$ & $\begin{array}{c}220 \\
61 \\
95 \cdot 6 \\
29 \cdot 9\end{array}$ & $\begin{array}{r}753 \\
245 \\
509 \\
1,824\end{array}$ & $\begin{array}{l}109 \\
200 \\
335 \\
88 \cdot 7\end{array}$ & $\begin{array}{l}75 \cdot 7 \\
49 \cdot 5 \\
202 \\
64 \cdot 1\end{array}$ & $\begin{array}{l}56 \cdot 0 \\
31 \cdot 2 \\
64 \cdot 2 \\
45 \cdot 7\end{array}$ & $\begin{array}{l}33 \\
28 \\
76 \\
90\end{array}$ & $\begin{array}{c}\text { Not tested } \\
4 \cdot 2 \\
1.5 \\
\text { Not tested } \\
\end{array}$ \\
\hline \multicolumn{3}{|c|}{ Normal values } & $0-5 \cdot 3$ & $0-3.6$ & $0-41$ & $0-280$ & $0-113$ & $0-50$ & $15-40$ & $0.3-0.9$ \\
\hline
\end{tabular}




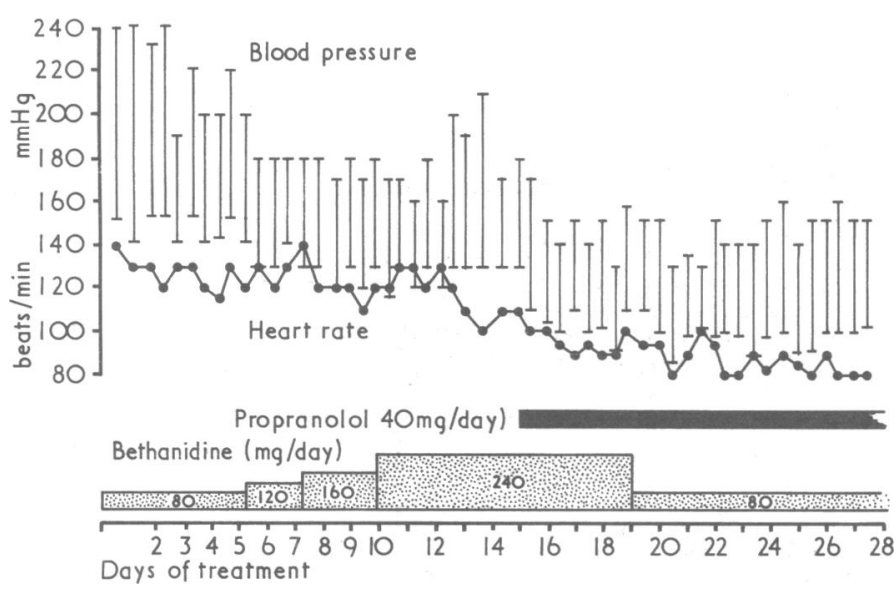

FIG. 1-Case 3. Blood pressure and heart rate response to bethanidine and propranolol.

After four weeks the blood pressure was stabilized at $150 / 100 \mathrm{~mm} \mathrm{Hg}$ and the pulse rate at $90 / \mathrm{min}$ and he was discharged on bethanidine $20 \mathrm{mg}$ by mouth four times a day and propranolol $10 \mathrm{mg}$ by mouth four times a day. He was readmitted with a further attack on 18 May, the blood pressure being $160 / 120 \mathrm{~mm} \mathrm{Hg}$. Bethanidine therapy was stopped and the oral dose of propranolol increased to $40 \mathrm{mg}$ sixhourly and after three days increased again to $100 \mathrm{mg}$ six-hourly. As the attack subsided and the blood pressure and pulse rate fell the dose of propranolol was reduced to $40 \mathrm{mg}$ six-hourly and this dose was continued after discharge. He continued to have attacks of severe pain about every three months, but the blood pressure was contained within an upper limit of $140 / 110 \mathrm{~mm} \mathrm{Hg}$ and was within normal limits during periods of remission.

Family History.-The patient's brother, sister, and paternal cousin died of acute intermittent porphyria at the ages of 21,18 , and 25 years respectively. No other relatives were known to suffer from the disease.

CASE 4

A 23-year-old hairdresser was admitted to hospital on 25 August 1971 because of abdominal pain, weakness of her arms and legs, and pain and stiffness in her shoulders. The pulse rate was $164 / \mathrm{min}$ and the rhythm regular. The blood pressure was $155 / 105 \mathrm{~mm}$ Hg. There was some epigastric tenderness but no other abdominal findings. Her voice was noticeably weak. Wrist-drop and foot-drop were present bilaterally and there was generalized hyporeflexia with flexor plantar responses. The diagnosis of acute intermittent porphyria had been established at another hospital three years previously after removal of a normal appendix because of abdominal pain. She had a second attack of pain and weakness in February 1970 two weeks before delivery of her only child.

The principal biochemical findings are shown in table I. The serum urea was $90 \mathrm{mg} / 100 \mathrm{ml}$ but quickly fell to normal, the electrocardiogram showed a sinus tachycardia, the chest $x$-ray picture was normal, and the electroencephalogram was within normal limits.

Treatment was started on the day after admission with propranolol $40 \mathrm{mg}$ eight-hourly and promazine $50 \mathrm{mg}$ three times a day. After about four days the pulse rate fell to about $100 / \mathrm{min}$, where it remained, and the blood pressure fell to $120 / 80 \mathrm{~mm} \mathrm{Hg}$. Five days after admission there was a transitory acute paranoid psychosis lasting about two hours. Thereafter the patient made slow but steady progress and by the time of discharge six weeks later much of the power had returned to her hands and feet. Propranolol therapy was stopped three days before discharge.

A further, less severe attack caused the patient to be readmitted on 17 December 1971. Tachycardia and hypertension were again noted and she was given propranolol $40 \mathrm{mg}$ four times a day together with promazine $50 \mathrm{mg}$ three times a day. The satisfactory reduction in pulse and blood pressure is shown in fig. 2.

Family History.-Quantitative porphyrin measurements were done on six members of this patient's family and her sister was found to be a carrier of the trait.

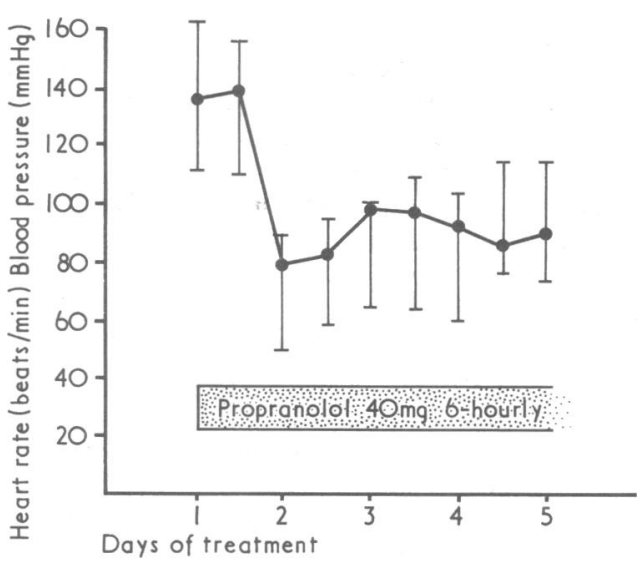

FIG. 2-Case 4. Blood pressure and heart rate response to propranolol on second admission.

\section{ANIMAL STUDIES}

The results of the animal studies are shown in table II. No significant change occurred in the hepatic activity of either ALA synthetase or ALA dehydrase in the rats given propranolol.

TABLE II-Effect of Propranolol on Rat Hepatic ALA Synthetase and ALA Dehydrase (Mean \pm S.D.)

\begin{tabular}{ll|c|c|c}
\hline \multicolumn{1}{c|}{ Treatment } & No. of Animals & $\begin{array}{c}\text { ALA Synthetase } \\
\text { Activity } \\
(\mu \mathrm{g} / \mathrm{g} \text { wet wt/hr) }\end{array}$ & $\begin{array}{c}\text { ALA Dehydrase } \\
\text { Activity } \\
\text { (nmol/g wet wt/hr) }\end{array}$ \\
\hline \begin{tabular}{ll|l} 
Propranolol \\
1mg/kg
\end{tabular} & $\ldots$ & 5 & $6.63 \pm 1.25$ & $1,148 \pm 41$ \\
Control & $\cdots$ & 5 & $7.59 \pm 1.39$ & $1,112 \pm 73$ \\
\hline
\end{tabular}

\section{Discussion}

Hypertension and tachycardia occur in more than $50 \%$ of patients with acute intermittent porphyria. In most cases the blood pressure and pulse subside to normal levels during remission of the disease. Because of the reported occurrence of retinopathy, encephalopathy, and left ventricular failure during porphyric attacks it is necessary in some cases to control hypertension by drug therapy. The treatment of hypertension in acute porphyria is not without difficulty. Methyldopa is contraindicated because it has been associated with a provocation of attacks (Le Roux, 1963), while bethanidine is not uniformly successful in reducing the blood pressure, as noted in case 3 . In the cases described the administration of propranolol was associated with a reduction in pulse rate and blood pressure together with an improvement in the patients' general condition.

The results of the experimental study with propranolol in rats are of interest. Hepatic ALA synthetase activity is known to be greatly increased in man during attacks of acute intermittent porphyria (Tschudy et al., 1965) and it is known that these drugs, which clinically provoke the disease, induce hepatic ALA synthetase in animals. Propranolol did not induce hepatic ALA synthetase in rats, and thus aggravation of porphyria is unlikely to be a consequence of its use.

The ability of propranolol to affect the hypertension and tachycardia of acute intermittent porphyria affords a possible insight into the cause or causes of these clinical signs. If the hypertension and tachycardia were the result of increased circulating levels of catecholamines or hypersensitivity of the receptor sites 
to catecholamines then a postsynaptic receptor-blocking drug such as propranolol would produce a depressor action. Schley et al. (1970) have shown an increase in urinary excretion of catecholamine metabolites in patients with acute intermittent porphyria during an attack, and this is probably a reflection of increased circulating levels of catecholamines. In the present study the urinary excretion of catecholamines was increased in both patients in whom the measurement was made. It is also possible that changes in receptor site sensitivity to circulating catecholamines could occur in the presence of lesions of the sympathetic nerves. Such lesions are known to exist in acute intermittent porphyria (Gibson and Goldberg, 1956).

Evaluation of the efficacy of drug treatment in acute intermittent porphyria is particularly difficult because of the relapsing and remitting course of the disease. This feature, together with the comparative rarity of the porphyrias, precludes the controlled clinical trial method of assessment. In the four patients described administration of propranolol seemed to be followed closely by a reduction in both heart rate and blood pressure and in one case (case 2) control of abdominal pain. At the same time the patients' general condition seemed to improve. On the basis of animal studies it is believed that propranolol will not aggravate the attack.

\section{References}

Dowdle, E. B., Mustard, P., and Eales, L. (1967). South African Medical fournal, 41, 1093.

Gibson, J. B., and Goldberg, A. (1956). Fournal of Pathology and Bacteriology, $71,495$.

Goldberg, A. (1959). Quarterly fournal of Medicine, N.S., 28, 183.

Granick, S. (1966). Fournal of Biological Chemistry, 241, 1359.

Le Roux, D. (1963). South African fournal of Laboratory and Clinical Medicine, 9, 308.

Marver, H. S., Tschudy, D. P., Perlroth, M. G., and Collins, S. (1966). fournal of Biological Chemistry, 241, 2803.

Mauzerall, D., and Granick, S. (1956). fournal of Biological Chemistry, 219, 435.

Melkersson, E. (1925). Acta Medica Scandinavica, 63, 153

Moore, M. R., Battistini, V., Beattie, A. D., and Goldberg, A. (1970), Biochemical Pharmacology, 19, 751.

Moore, M. R., Beattie, A. D., Thompson, G. G., and Goldberg, A. (1971). Clinical Science, 40, 81 .

Pisano, J. J. (1960). Clinica Chimica Acta, 5, 406

Rimington, C. (1961). Association of Clinical Pathologists, Broadsheet, No. 36 Schley, G., et al. (1970). Klinische Wochenschrift, 41, 36.

Tschudy, D. P., et al. (1965). Proceedings of the National Academy of Sciences $53,841$.

Waldenström, J. (1937). Acta Medica Scandinavica, Suppl. No. 82.

\title{
Foot Infections in Swimming Baths
}

\author{
J. C. GENTLES, E. G. V. EVANS
}

British Medical fournal, 1973, 3, 260-262

\section{Summary}

A $10 \%$ random sample of all bathers at a public swimming bath were examined for tinea pedis and verruca.

The overall incidence of tinea pedis was $8.5 \%$ and of verruca $4.8 \%$. The incidence of tinea pedis in 205 male adults was $21.5 \%$, in 288 boys $6.3 \%$, in 60 adult females $3.3 \%$, and in 220 girls $0.9 \%$. The incidence of verruca in juveniles ranged from $4.2 \%$ in boys to $10.5 \%$ in girls.

It was clear that both infections spread within the baths, and since a relatively small proportion of users admitted to taking precautions to avoid contracting or developing infections it seems advisable that more publicity about recommendations on foot care should be provided.

\section{Introduction}

The role of communal bathing places such as indoor swimming pools in the spread of foot infections has been well established. The incidence of infection in bathers at such establishments, however, has never been fully investigated nor have there been many attempts to determine a procedure which might minimize the risk to bathers. This paper presents the results of an investigation of the incidence of infections with dermatophytes (tinea pedis) at a new swimming pool in the West of Scotland before the introduction of a procedure aimed at reducing the spread of infection. The incidence of verruca was also noted.

\footnotetext{
Department of Dermatology, University of Glasgow, Glasgow G11 6NU

J. C. GENTLES, B.SC., PH.D., Reader in Medical Mycology

Departments of Dermatology and Microbiology, University of Leeds, and General Infirmary at Leeds, Leeds LS1 3EX

E. G. V. EVANS, B.SC., Lecturer in Medical Mycology
}

\section{Methods}

The swimming bath is a covered, heated, international-class pool opened 18 months before the survey. An average of 8,000 bathers enter the pool each week, a large number of whom are visitors from surrounding townships. On entry those under 16 years of age are classified as juveniles.

A $10 \%$ random sample of bathers was selected by means of an electronic counting machine from those using the pool over a period of one week. The selected bathers were first interviewed and personal details including swimming habits were recorded on specially prepared cards. Their feet were examined and their clinical condition, including the presence of any verrucae, noted. Scrapings were taken, whenever possible, from the 4th toe clefts of both feet and from any other clinically suspicious sites. In most cases the material collected from each subject was pooled. When the skin of the toe clefts was so smooth that it was impossible to collect material without inducing trauma the bather was regarded as clear of infection.

Samples were processed using routine methods for laboratory diagnosis of superficial fungal infections-namely, culture on $4 \%$ malt extract agar of 12 inocula at $28^{\circ} \mathrm{C}$ and direct microscopy in $20 \%$ potassium hydroxide.

The statistical validity of the results was assessed using the $\chi^{2}$ test.

\section{Results}

A summary of the results is shown in table I. A total of 8,291 bathers entered the pool during the sampling week and of these $773(9.3 \%)$ were interviewed and examined. A further 75 were selected but either did not appear for examination or refused.

Of the 773 persons examined a specimen could not be obtained from $118(15 \%)$ and on a further 226 (29\%) occasions the material that could be obtained was insufficient to allow either the full number of inocula for culture or micros- 